\title{
Cytotoxic activity of crude extracts from Datura stramonium's fungal endophytes against A549 lung carcinoma and UMG87 glioblastoma cell lines and LC-QTOF-MS/MS based metabolite profiling
}

Kudzanai lan Tapfuma', Nkemdinma Uche-Okereafor ${ }^{1}$, Tendani Edith Sebola', Raeesa Hussan², Lukhanyo Mekuto ${ }^{3}$, Maya Mellisa Makatini ${ }^{4}$, Ezekiel Green ${ }^{1}$ and Vuyo Mavumengwana ${ }^{2^{*}}$ (D

\begin{abstract}
Background: Endophytic fungi are a proven source of bioactive secondary metabolites that may provide lead compounds for novel drug discovery. In this study, crude extracts from fungal endophytes isolated from Datura stramonium were evaluated for cytotoxic activity on two human cancer cell lines.

Methods: Fungal endophytes were isolated from surface sterilized aerial parts of D. stramonium and identified using molecular, morphological and phylogenetic methods. Ethyl acetate crude extracts from these isolates were evaluated for cytotoxic activity on A549 lung carcinoma and UMG87 glioblastoma cell lines. Metabolite profiling was then performed by liquid chromatography coupled to quadrupole time-of-flight with tandem mass spectrometry (LC-QTOF-MS/MS) for the cytotoxic crude extract.
\end{abstract}

Results: Eleven fungal endophytes were identified from D. stramonium. Significant cytotoxicity was only observed from the crude extract of Alternaria sp. KTDL7 on UMG87 glioblastoma cells $\left(I C_{50}=21.49 \mu \mathrm{g} / \mathrm{ml}\right)$. Metabolite profiling of this crude extract tentatively revealed the presence of the following secondary metabolites: 1,8-dihydroxynaphthalene (1), anserinone B (2), phelligridin B (3), metacytofilin (4), phomopsidin (5) and vermixocin A (6). Compounds 2 and 3 have been shown to be cytotoxic in literature.

Conclusion: The findings in this study suggest that the crude extract of Alternaria sp. KTDL7 possesses compound(s) cytotoxic to glioblastoma multiforme cells. Future studies to isolate and characterize the cytotoxic compound(s) from this fungus could result in lead development of a fungal-based drug for glioblastoma multiforme treatment.

Keywords: Datura stramonium, Endophytes, Secondary metabolites, Lung carcinoma, Glioblastoma, Cytotoxicity

\section{Background}

Internal tissues of plants are habitats of a class of beneficial endosymbiotic microorganisms (predominantly bacteria and fungi) called endophytes that have been observed in all plants investigated to date [1]. In this plant-endophyte relationship, plants are hosts which

\footnotetext{
* Correspondence: vuyom@sun.ac.za

${ }^{2}$ South African Medical Research Council Centre for Tuberculosis Research, Division of Molecular Biology and Human Genetics, Department of Biomedical Sciences, Stellenbosch University, Tygerberg 7505, South Africa Full list of author information is available at the end of the article
}

generally offer nourishment and protection while endophytes improve plant defense, health and stress tolerance by solubilizing phosphates, fixing nitrogen, secreting siderophores, hydrolytic enzymes, antimicrobials or by producing plant hormones such as indole-3-acetic acid $[2,3]$.

In comparison to free living fungi, crude extracts of fungal endophytes are an underexplored but rich source of bioactive and chemically diverse secondary metabolites which include terpenoids, alkaloids, phenols, furandiones, dimeric anthrones and benzopyroanones $[4,5]$. 
This is evidenced by a detailed review of 46 genera and 111 species of fungal endophytes producing cytotoxic secondary metabolites by Chen et al. [6]. In order to increase the likelihood of isolating fungal endophytes that produce medicinally important secondary metabolites, documented medicinal plants that are used in traditional medicine are targeted [5].

Datura stramonium is a medicinal plant that is known for producing over 64 tropane alkaloids of which atropine, scopolamine and hyoscyamine are predominantly found in relatively high concentrations $[7,8]$. While ethnomedical uses of $D$. stramonium include inhalation of smoke from burnt leaves to relieve symptoms of asthma, bronchitis, sedation, epilepsy and psychosis to name just a few [8], exploration into the use of tropane alkaloids as potentially anticancer lead compounds has been ongoing since the early 2000s [9]. Bacterial and fungal endophytes have been previously isolated from $D$. stramonium in studies focusing on the potential use of endophytic extracts as biocontrol agents for controlling plant and human pathogens [10-13], in vitro $\alpha$-glucosidase inhibitors and antioxidant agents [14]. To the best of our knowledge, this is the first study that reports the cytotoxic activity of crude extracts endophytic fungi from $D$. stramonium on human A549 lung carcinoma and UMG87 glioblastoma cell lines. The results of the bioactive crude extract observed in this study may form a foundation for developing a fungalderived drug for glioblastoma multiforme treatment.

\section{Methods}

\section{Collection of plant material}

Healthy free growing D. stramonium plants were collected in summer in Johannesburg (South Africa) at the following coordinates: $26^{\circ} 13^{\prime} 04.5^{\prime \prime} \mathrm{S}, 28^{\circ} 12^{\prime} 48.3^{\prime \prime} \mathrm{E}$. Plant diversity and vegetative growth on the site were high with different species interspersed between $D$. stramonium. Plant samples were transferred to the laboratory immediately after collection and were thoroughly washed with distilled water upon arrival. Formal identification of the collected plants was done by Abdulwakeel Ayokun-nun Ajao, a botanist from the Department of Botany and Plant Biotechnology at the University of Johannesburg. A voucher specimen of the whole plant was deposited in the department's public herbarium and was assigned deposition number RAM-001.

\section{Isolation and morphological characterization of fungal endophytes}

The isolation of fungal endophytes was done on the same day of collection following a modified method described by Uche-Okereafor et al., [15]. Briefly, $10 \mathrm{~g}$ of each of the aerial plant parts (stems, leaves, fruit covers and seeds) were separately soaked in $5 \%$ Tween 80 , adequate to cover each sample for five minutes with vigorous shaking. This was subsequently followed by washing the samples several times with sterile distilled water to remove Tween 80 . Samples were then dipped in $70 \%$ ethanol for $1 \mathrm{~min}$ and rinsed with sterile distilled water five times, followed by dipping in $1 \%$ sodium hypochlorite for $10 \mathrm{~min}$. Plant parts were then finally rinsed five times with sterile distilled water and aliquots of $50 \mu \mathrm{L}$ of the last rinse water for each sample were plated on potato dextrose agar (PDA) (Merck, Johannesburg, SA) as wash controls to determine the effectiveness of surface sterilization. The surface sterilized samples were then macerated in sterile phosphate buffered saline (PBS) (Oxoid, Basingstoke, Hampshire, UK) solution using a sterile mortar and pestle. Serial dilutions of macerated samples were made by pipetting $1 \mathrm{~mL}$ of macerated sample into $9 \mathrm{~mL}$ of PBS to make a $10^{-1}$ dilution, followed by subsequent dilutions up to $10^{-9}$. The serial dilutions were then plated in triplicates on PDA for enumeration of fungal endophytes and incubated at $28^{\circ} \mathrm{C}$ (IncoTherm, Labotec, Johannesburg, SA) for up to 21 days. Morphologically distinct fungal isolates were then sub-cultured several times to obtain pure isolates. Fungi were differentiated from bacteria using lactophenol cotton blue staining. Lactophenol cotton blue is a dye which stains chitin in fungal cell walls blue [16].

\section{Molecular characterization (rDNA-ITS sequencing and phylogenetic analysis)}

DNA extraction was done using the ZR Fungal/Bacterial DNA Kit ${ }^{\mathrm{mt}}$ (Zymo Research, Irvine, CA, USA), following the manufacturer's instructions. Polymerase chain reaction (PCR) was done to amplify the internal transcribed spacer (ITS) region of ribosomal DNA (rDNA) using the ITS1 (5'-TCCGTAGGTGAACCTGCGG-3') and ITS4 (5'-TCCTCCGCTTATTGATATGC-3') primer pair. Forward and reverse direction sequencing was done using the ABI PRISM ${ }^{\mathrm{Tm}}$ 3500xl Genetic Analyzer (Thermo Fisher Scientific, Inc., Waltham, MA, USA) followed by the purification of the sequencing products using ZR-96 DNA Sequencing Clean-up Kit ${ }^{\text {tix }}$ (Zymo Research, Irvine, CA, USA). DNA sequences were then analyzed using the FinchTV software [17], followed by a Nucleotide Basic Local Alignment Search (BLASTN) on the National Center for Biotechnology Information (NCBI) using the GenBank database to identify closely matching organisms [18]. The sequences used in the molecular data sets ranged from 450 to 700 base pairs prior to deletion of ambiguous data occurring at the beginning or at the end of each sequence [19]. Maximum likelihood phylogenetic reconstruction was done using MEGA version 7.0 software [20], with Dothidea insculpta and Monochaetia monochaeta as outgroups. Bootstrap values were calculated from 1000 replicate runs. Phylogenetic reconstruction of isolates was done by grouping isolates according to morphological 
characteristics observed on PDA cultures. The rDNA-ITS sequences were then submitted to GenBank.

\section{Shannon-Weiner diversity index $\left(H^{\prime}\right)$}

Fungal endophyte diversity was determined by the Shannon-Wiener diversity index $\left(H^{\prime}\right)$, using the formulae below:

$$
H \ddot{E}=\Sigma(P i \times \ln P i), P i=\frac{m i}{N} .
$$

where mi represents number of individuals and $\mathrm{N}$ represents the total number of individuals [21].

\section{Fermentation and extraction of secondary metabolites}

Fungal endophytes were fermented as monocultures in $3 \mathrm{~L}$ of PDB (Potato infusion $200 \mathrm{~g} / \mathrm{L}$, dextrose $20 \mathrm{~g} / \mathrm{L}$ ) [22]. Incubation was done for 21 days at $28^{\circ} \mathrm{C}$ in an orbital shaking incubator (Amerex Gyromax, Temecula, CA, USA) at $150 \mathrm{rpm}$. After fermenting the fungi, extrolites which are mainly secondary metabolites were extracted from broth monocultures using analytical grade ethyl acetate [23]. This extraction was achieved by firstly filtering the broth monocultures through a Whatman No. 1 filter paper to separate the mycelia from the broth culture. Equal volumes of ethyl acetate and filtrate broth were then added to a separating funnel, shook vigorously to mix the two liquids and allowed to stand for $20 \mathrm{~min}$. The organic solvent phase was then collected and concentrated using a rotary evaporator under reduced pressure at $40^{\circ} \mathrm{C}$ and the resulting crude extracts were allowed to air dry and consequently stored at $-20^{\circ} \mathrm{C}$.

\section{MTS assay on UMG87 glioblastoma and A549 lung carcinoma cell lines}

End-point cytotoxicity evaluation of crude extracts on UMG87 glioblastoma and A549 lung carcinoma cell lines (ATCC, Manassas, VA, USA) was performed following the colorimetric MTS [3-(4,5-dimethylthiazol-2yl)-5-(3-carboxymethoxyphenyl)-2-(4-sulfophenyl)- $2 \mathrm{H}$ tetrazolium] assay method $[6,10]$. Cells at $5 \times 10^{4}$ cells/ $\mathrm{mL}$ were initially seeded in 96 well plates containing Dulbecco's modified eagle medium (Gibco, Carlsbad, CA, USA) with $15 \%$ heat inactivated fetal bovine serum (Merck, Johannesburg, SA) and incubated at $37^{\circ} \mathrm{C}$ in $5 \%$ $\mathrm{CO}_{2}(\mathrm{v} / \mathrm{v})$ for $24 \mathrm{~h}$ [24]. Crude fungal extracts and auranofin (a positive control) were then dissolved in dimethyl sulfoxide (DMSO) (Merck, Johannesburg, SA) and then added to cell cultures at concentrations of $3.13,6.25,12.5,25,50$ and $100 \mu \mathrm{g} / \mathrm{mL}$, in triplicates. The cell cultures were then left to incubate for a further $96 \mathrm{~h}$, after which $5 \mu \mathrm{l}$ of MTS (Promega, Madison, WI, USA) was added to the cells and absorbance values measured at $490 \mathrm{~nm}$ after 1, 2 and 4-h incubation periods. Cell viability was calculated using the following formulae:

$$
\text { \%Cell Viability }=\frac{E_{a}-B_{a}}{C_{a}-B_{a}} \times 100
$$

where $E_{a}$ is absorbance of the extract, $B_{a}$ is absorbance of the blank and $C_{a}$ is the absorbance of the negative control (untreated cells) [25]. GraphPad Prism software (v. 7.05, GraphPad Software, Inc., La Jolla, CA, USA) was used to produce dose response curves by non-linear regression analysis of cell viability data, hence determining the mean inhibitory concentration $\left(\mathrm{IC}_{50}\right)$ value.

\section{xCELLigence ${ }^{\oplus}$ real-time cell analyzer (RTCA) assay on U87MG glioblastoma cells}

xCELLigence ${ }^{\circ}$ RTCA assay was performed by initially seeding $1 \times 10^{5}$ cells $/ \mathrm{mL}$ of U87MG glioblastoma cells on gold microelectrode precoated 96 well electronic plates (E-Plate ${ }^{\oplus}$ 96, ACEA Biosciences Inc., San Diego, CA, USA) and incubating at $37^{\circ} \mathrm{C}$ in $5 \% \mathrm{CO}_{2}(\mathrm{v} / \mathrm{v})$ for $45 \mathrm{~h}$. Selected crude fungal extracts and auranofin (a positive control) were then dissolved in DMSO and then added at concentrations of $3.13,6.25,12.5,25,50$ and $100 \mu \mathrm{g} / \mathrm{mL}$, in triplicates. Untreated cells $(0 \mu \mathrm{g} / \mathrm{mL})$ were included as a negative control. The cell cultures were then incubated for a further $171 \mathrm{~h}$, with impedance measurements taken every $15 \mathrm{~min}$ during the total incubation period of $216 \mathrm{~h}$. The data was retrieved, and a graphic representation of the bioactivity was reproduced.

\section{Metabolite profiling of fungal crude extracts by LC-QTOF- MS/MS}

Metabolite profiling of the cytotoxic fungal extract was done by liquid chromatography coupled to a quadrupole time-of-flight with tandem mass spectrometry (LCQTOF-MS/MS), using a previously described modified method [26, 27]. This system has a Dionex UltiMate 3000 ultra-high-performance liquid chromatography (UHPLC) (Thermo Scientific, Darmstadt, Germany) coupled to a Compact $^{\text {tux }}$ QTOF (Bruker Daltonics, Bremen, Germany) that uses an electrospray ionization (ESI) interface. The crude extract of the fungal endophyte Alternaria sp. KTDL7 was prepared for analysis by dissolving $1 \mathrm{mg} / \mathrm{mL}$ $(w / v)$ in HPLC grade methanol (Merck, Johannesburg, $\mathrm{SA}$ ), followed by sonication for $10 \mathrm{~min}$, and finally filtration through $0.22 \mu \mathrm{m}$ polyvinylidene fluoride (PVDF) membrane syringe filters into $1 \mathrm{~mL} \mathrm{LC}$ auto-sampler vials. An injection volume of $5 \mu \mathrm{L}$ was used in the system for chromatographic separation of analytes in reverse phase ultra-high-performance liquid chromatography (RPUHPLC) through a Raptor ARC-18 column with dimensions of $2.7 \mu \mathrm{m}$ (particle size), $2.1 \mathrm{~mm}$ (internal diameter), $100 \mathrm{~mm}$ (length) and $90 \AA$ (pore size) (Restek, Bellefonte, PA, USA). The mobile phase was composed of solvent A (A) consisting of $0.1 \%$ formic acid in $\mathrm{H}_{2} \mathrm{O}(\mathrm{v} / \mathrm{v})$ and solvent $\mathrm{B}$ (B) consisting of $0.1 \%$ formic acid in acetonitrile ( $\mathrm{v} /$ 
v). Gradient flow of the mobile phase was initiated by a $2.0 \mathrm{~min}$ isocratic step at $5 \% \mathrm{~B}$ followed by an increase to $95 \%$ in $28 \mathrm{~min}$, an isocratic step at $95 \%$ B for $5 \mathrm{~min}$ followed by a decrease to $5 \% \mathrm{~B}$ in $1 \mathrm{~min}$ upon reequilibration to initial conditions at a flow rate of $300 \mu \mathrm{L} /$ min. The ESI(+) parameters were as follows: set capillary voltage at $4.5 \mathrm{kV}$; end plate offset at $-500 \mathrm{~V}$; dry heater temperature at $220{ }^{\circ} \mathrm{C}$; dry gas flow rate at $2.5 \mathrm{~L} / \mathrm{min}$ and nebulizer gas pressure at 1.8 Bar. Mass spectra were acquired in centroid mode ranging from 50 to $1300 \mathrm{~m} / \mathrm{z}$ [28]. Instrument operation, control and data acquisition was done using HyStar software version 2.10 (Thermo Scientific, Darmstadt, Germany). Spectral data processing was performed in Bruker Compass DataAnalysis software version 4.3 (Bruker Daltonics, Bremen, Germany). MetFrag web tool version 2.1 (https://msbi.ipb-halle.de/MetFragBeta/) was used to characterize the resulting fragment spectra by linking to three compound databases, namely PubChem, ChemSpider and KEGG [29]. The MetFrag settings used were as follows: The MetFrag database search settings used were as follows: Database search relative mass deviation (Search $\mathrm{ppm})=10.0$; precursor ion $=[\mathrm{M}+\mathrm{H}]^{+}$; fragment peak match absolute mass deviation $($ Mzabs $)=0.01$; fragment peak match relative mass deviation $(\mathrm{Mzppm})=10 ;$ charge $=$ positive and mode $=[\mathrm{M}+\mathrm{H}]^{+}$.

\section{Statistical analysis}

Quantitative variables were analyzed in STATISTICA version 10 (StatSoft, Inc., Tulsa, OK, USA). Multivariate analysis of variance (MANOVA) and the least significant difference (LSD) post hoc were used to analyze the mean \pm standard deviation $(\mathrm{SD})$ of crude extracts at various concentrations. A probability of $P \leq 0.05$ was taken to indicate statistical significance.

\section{Results}

Isolation, characterization and identification of culturable fungal endophytes

In this study, 11 culturable fungal endophytes were recovered from $D$. stramonium (seven isolates from the leaves, three from the stems and one from the seeds). Examination of morphological macroscopic and microscopic features revealed that four out of eleven were filamentous fungi. Analysis of the ITS sequences resulted in the taxonomic classification of five fungal isolates to species level with the rest only classified to genus level (Table 1). These results corroborated with the phylogenetic reconstruction which grouped isolates according their respective genera and species (see Additional file 1). The Shannon-Weiner diversity index $\left(H^{\prime}\right)$ for the isolated endophytes was calculated and found to be 3.44 with the highest diversity observed in isolates from the leaves. This diversity index takes into account homogeneity/heterogeneity of isolates and usually ranges between 1.5 to 4.5 , where the higher values correspond to increase in species diversity [30].

\section{MTS cytotoxicity assay on A549 lung carcinoma cells}

Statistically significant differences in the effect of fungal crude extracts on A549 lung carcinoma cells were observed at $P \leq 0.05$ level even though the cytotoxicity observed was limited. Cell viability ranged from 92.2 to $146.9 \%$, reflecting limited inhibitory effect presented by the fungal crude extracts during the incubation period of $96 \mathrm{~h}$ (Fig. 1). Cell viability of above $100 \%$ was mostly observed for the highest concentrations of fungal crude extracts $(25,50$ and $100 \mu \mathrm{g} / \mathrm{mL})$, which may typically have resulted from the antioxidant potential of compounds in fungal crude extracts, causing elevated absorbance values for the reduced of MTS product (formazan) that are higher than those observed in the negative control cells $[31,32]$.

\section{MTS cytotoxicity assay on UMG87 glioblastoma cells}

The crude fungal extract from Alternaria sp. KTDL7 showed the highest antiproliferative activity on UMG87 glioblastoma cells, recording the lowest cell viability of $2.68 \%$ at $50 \mu \mathrm{g} / \mathrm{mL}$, followed by $4.29 \%$ at $100 \mu \mathrm{g} / \mathrm{mL}$ (Fig. 1). Multi-variate analysis of variance test of the means from the two concentrations showed that their cytotoxic activity had no significant difference since $P>0.05$. Furthermore, the cytotoxic effects of these two concentrations from Alternaria sp. KTDL3 were found to be comparable with that of auranofin on the same cell line at treatments of $12.5-100 \mu \mathrm{g} / \mathrm{mL}$ (Fig. 1). The $\mathrm{IC}_{50}$ value for the fungal extract from Alternaria sp. KTDL7 was determined by plotting a dose-response curve (Fig. 2) and was found to be $21.49 \mu \mathrm{g} / \mathrm{mL}$, just below the American National Cancer Institute guidelines (NIC) for preliminary screening assays which state that crude extracts achieving $50 \%$ antiproliferative activity at $<30 \mu \mathrm{g} / \mathrm{mL}$ after $72 \mathrm{~h}$ of exposure are to be regarded as cytotoxic $[33,34]$.

\section{xCELLigence ${ }^{\circledast}$ RTCA assay on UMG87 glioblastoma cells}

UMG87 glioblastoma cells were exposed to selected fungal crude extracts of $A$. alternata KTDL3, Bipolaris sp. KTDS5 and Alternaria sp. KTDL7 which was initially observed to induce cytotoxicity on this cell line. Response of the cells to the fungal extracts was monitored for $171 \mathrm{~h}$ using a RTCA system. A dose-dependent inhibition was observed for the crude extract of Alternaria sp. KTDL7, where the highest concentration of $100 \mu \mathrm{g} /$ $\mathrm{mL}$ induced an irreversible cytotoxic effect on the UMG87 glioblastoma cells as shown in Fig. 3. Cells exposed to $100 \mu \mathrm{g} / \mathrm{mL}$ of the crude extract were unable show significant recovery from the cytotoxic effects from 
Table 1 Eleven fungal endophytes isolated from D. stramonium

\begin{tabular}{|c|c|c|c|c|c|c|}
\hline $\begin{array}{l}\text { Fungal } \\
\text { isolate }\end{array}$ & $\begin{array}{l}\text { Accession } \\
\text { number }\end{array}$ & Closest relatives in $\mathrm{NCBI}$ & $\begin{array}{l}\text { ITS identity } \\
(\%)\end{array}$ & Tissue & Phylum; Class; Order & Classification \\
\hline KTDL1 & MF952612 & Gyroporus castaneus Gc1 (EU718099) & 88 & Leaves & $\begin{array}{l}\text { Basidiomycota; Agaricomycetes; } \\
\text { Boletales }\end{array}$ & Gyroporus sp. \\
\hline KTDL2 & MF952613 & $\begin{array}{l}\text { Alternaria tenuissima Isolate } 4 \\
\text { (KU937315) }\end{array}$ & 97 & Leaves & $\begin{array}{l}\text { Ascomycota; Dothideomycetes; } \\
\text { Pleosporales }\end{array}$ & A. tenuissima \\
\hline KTDL3 & MF952614 & A. alternata CS36-4 (KY814634) & 100 & Leaves & $\begin{array}{l}\text { Ascomycota; Dothideomycetes; } \\
\text { Pleosporales }\end{array}$ & A. alternata \\
\hline KTDL4 & MF952615 & Colletotrichum sp. LTL119 (MF663557) & 100 & Leaves & $\begin{array}{l}\text { Ascomycota; Sordariomycetes; } \\
\text { Glomerellales }\end{array}$ & Colletotrichum sp. \\
\hline KTDL6 & MF952616 & $\begin{array}{l}\text { Talaromyces sp. SWP-2017 k NRRL } \\
62271 \text { (KX657354) }\end{array}$ & 89 & Leaves & $\begin{array}{l}\text { Ascomycota; Eurotiomycetes; } \\
\text { Eurotiales }\end{array}$ & Talaromyces sp. \\
\hline KTDL7 & MF952617 & Alternaria sp. XN-3-1 (KR822138) & 100 & Leaves & $\begin{array}{l}\text { Ascomycota; Dothideomycetes; } \\
\text { Pleosporales }\end{array}$ & Alternaria sp. \\
\hline KTDL8 & MF952618 & $\begin{array}{l}\text { Sporothrix schenckii CBS } 211.61 \\
\text { (KP017093) }\end{array}$ & 100 & Leaves & $\begin{array}{l}\text { Ascomycota; Sordariomycetes; } \\
\text { Ophiostomatales }\end{array}$ & Sporothrix schenckil \\
\hline KTDL11 & MF952619 & $\begin{array}{l}\text { Trichoderma longibrachiatum FIB PRI } 6.2 \\
\text { (LC106115) }\end{array}$ & 91 & Seeds & $\begin{array}{l}\text { Ascomycota; Sordariomycetes; } \\
\text { Hypocreales }\end{array}$ & Trichoderma sp. \\
\hline KTDS1 & MF952620 & $\begin{array}{l}\text { Pilobolus crystallinus 007pNNP } \\
\text { (KP760865) }\end{array}$ & 98 & Stem & $\begin{array}{l}\text { Zygomycota; Mucoromycotina; } \\
\text { Mucorales }\end{array}$ & $\begin{array}{l}\text { Pilobolus } \\
\text { crystallinus }\end{array}$ \\
\hline KTDS2 & MF952621 & $\begin{array}{l}\text { Rhodotorula mucilaginosa Feni } 103 \\
\text { (KP223714) }\end{array}$ & 99 & Stem & $\begin{array}{l}\text { Basidiomycota; Urediniomycetes; } \\
\text { Sporidiales }\end{array}$ & $\begin{array}{l}\text { Rhodotorula } \\
\text { mucilaginosa }\end{array}$ \\
\hline KTDS5 & MF952622 & Bipolaris setariae GP14 (KR183790) & 99 & Stem & $\begin{array}{l}\text { Ascomycota; Dothideomycetes; } \\
\text { Pleosporales }\end{array}$ & Bipolaris sp. \\
\hline
\end{tabular}

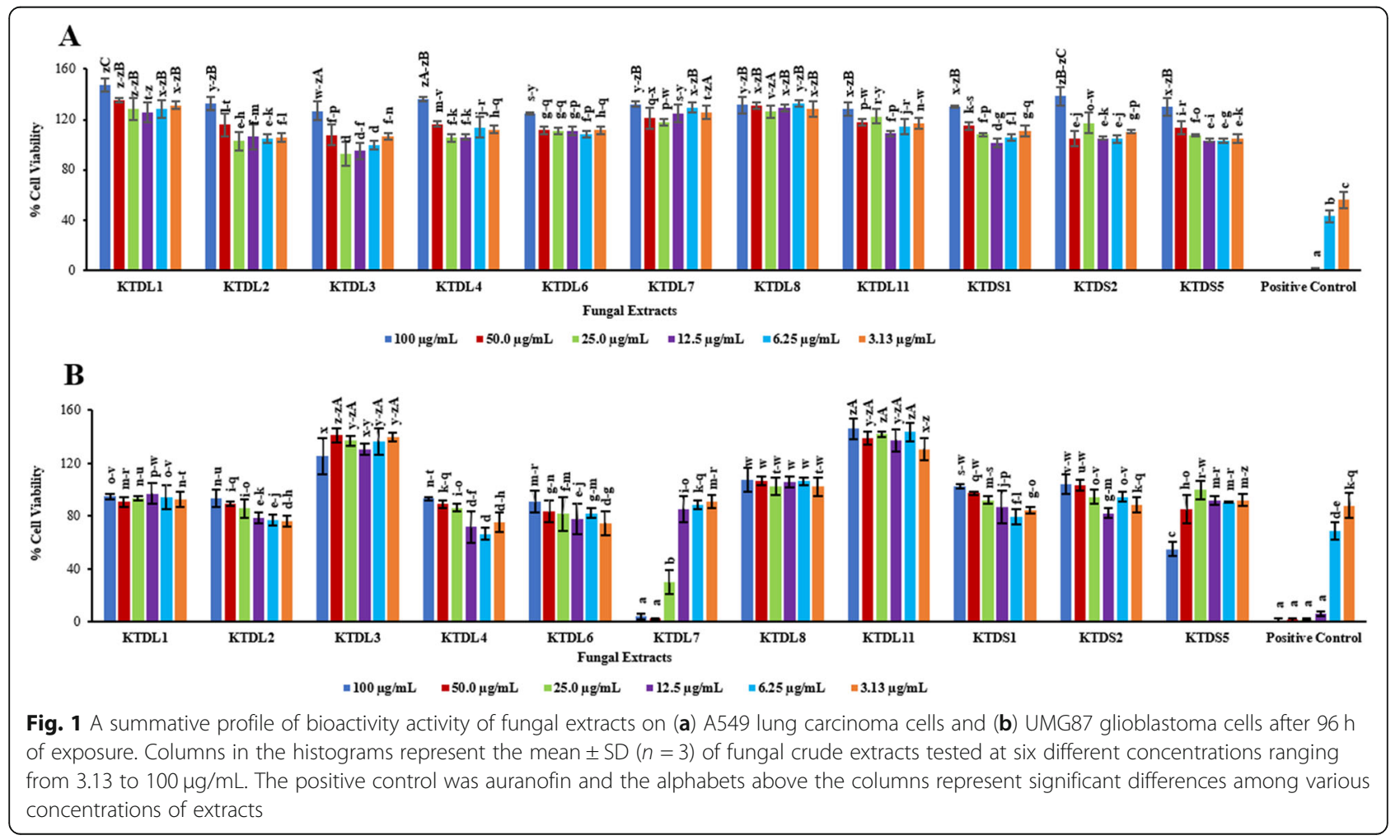




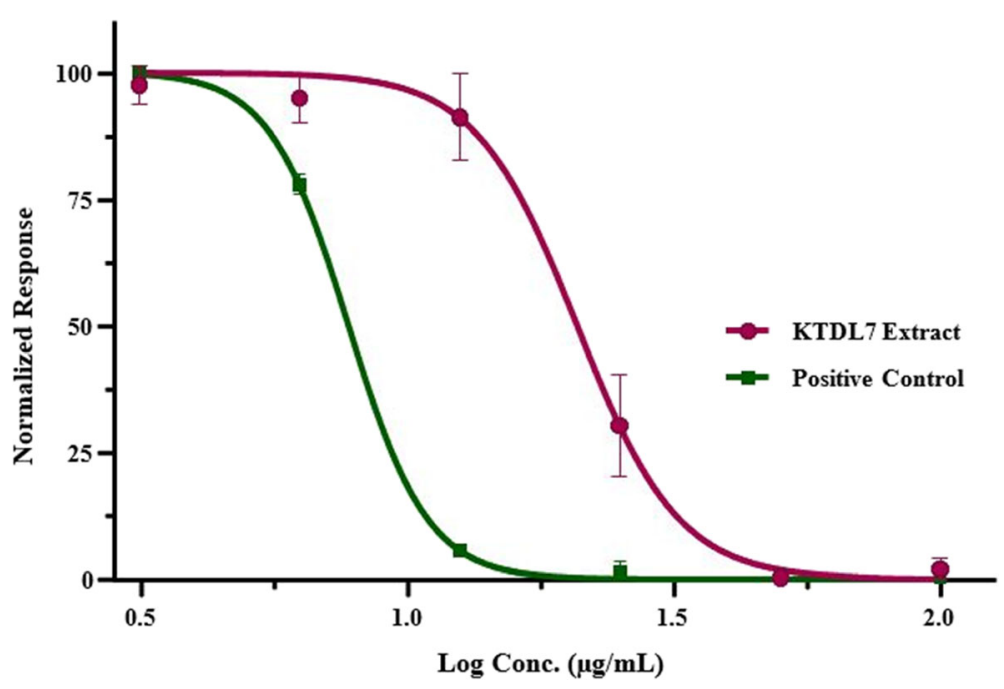

Fig. 2 Dose-response inhibition curve of the crude extract of Alternaria sp. KTDL7 on UMG87 glioblastoma cells

the point of exposure at the 45th hour to the 216th hour on the timeline.

Auranofin (a positive control) had a striking effect on UMG87 glioblastoma cells as some concentrations seemed to promote hyper metabolism than inhibit it. Exposure of the cells to a drug concentration of $6.25 \mu \mathrm{g} / \mathrm{mL}$ at the 45th hour resulted in an immediate decline in cell viability followed by a recovery and surge in viability from the 96th hour which exceeded the cell viability of the negative control $(0 \mu \mathrm{g} / \mathrm{mL})$ and cells treated with $3.13 \mu \mathrm{g} /$ $\mathrm{mL}$ of the drug. The surge in viability of cells treated with $6.25 \mu \mathrm{g} / \mathrm{mL}$ of auranofin at the 96th hour could be associated with development of antineoplastic resistance of surviving cells, leading them to overcome the cytotoxic effects of auranofin by upregulation of metabolic genes and thus leading to a spike in cell viability. Mechanisms of drug resistance in glioblastoma cells have been reviewed in Haar et al., [35]. Similar to the MTS assay, no significant cytotoxic activity was observed for the crude extracts of $A$. alternata KTDL3 and Bipolaris sp. KTDS5.

\section{Metabolite profiling of Alternaria sp. KTDL7's crude extract by LC-QTOF-MS/MS}

Secondary metabolites in the crude extract of Alternaria sp. KTDL7 were tentatively identified using an untargeted screening method. The impact of PDB on the fungal crude extract was considered by analyzing the spectrum of PDB and subtracting it from the spectrum of the fungal crude extract. Secondary metabolites were identified using the spectral information of molecular ions and their collision induced dissociation (CID) fragments which were compared with reference compounds and their in-silico fragments in online databases (Fig. 4) [36]. The identified compounds are as follows: 1,8-dihydroxynaphthalene (1), anserinone B (2), phelligridin B
(3), metacytofilin (4), phomopsidin (5) and vermixocin A (6). CID mass fragment data is available in Additional file 2.

\section{Discussion}

Medicinal plants with known ethnopharmacological properties are proven sources for isolation of endophytes that produce secondary metabolites with novel and medically significant bioactivities [21, 37]. The surface sterilization method of isolating endophytes is highly effective to reduce contamination of epiphytes when sodium hypochlorite is employed [38]. In this study, efficacy of surface sterilization was validated by plating on PDA the last rinse water used in the surface sterilization process as a control. No microbial growth was observed on these plates.

The Shannon-Wiener diversity index $\left(H^{\prime}\right)$ for the isolated endophytes was calculated and found to be 3.44, indicating a high species diversity among the fungal endophyte community in D. stramonium. Greatest diversity was observed in the leaves where the highest number of isolates were recovered with the Alternaria genus being the most prevalent. This genus has been previously reported as an endophyte in D. stramonium [39], while also being a pathogen in other plants of a different species which include cereals, strawberries and tomatoes [40]. Interestingly, pathotypes of the Alternaria genus mostly occur as foliar pathogens which produce hostselective toxins (HSTs) to target the above-mentioned susceptible plants [41]. Both the endophytes and pathotypes of this genus are rarely isolated from the seeds and roots, and less frequently from the stems [40-43].

The three endophytes from the Alternaria genus ( $A$. tenuissima KTDL2, A. alternata KTDL3 and Alternaria sp. KTDL7) produced varying shades of dark brown 

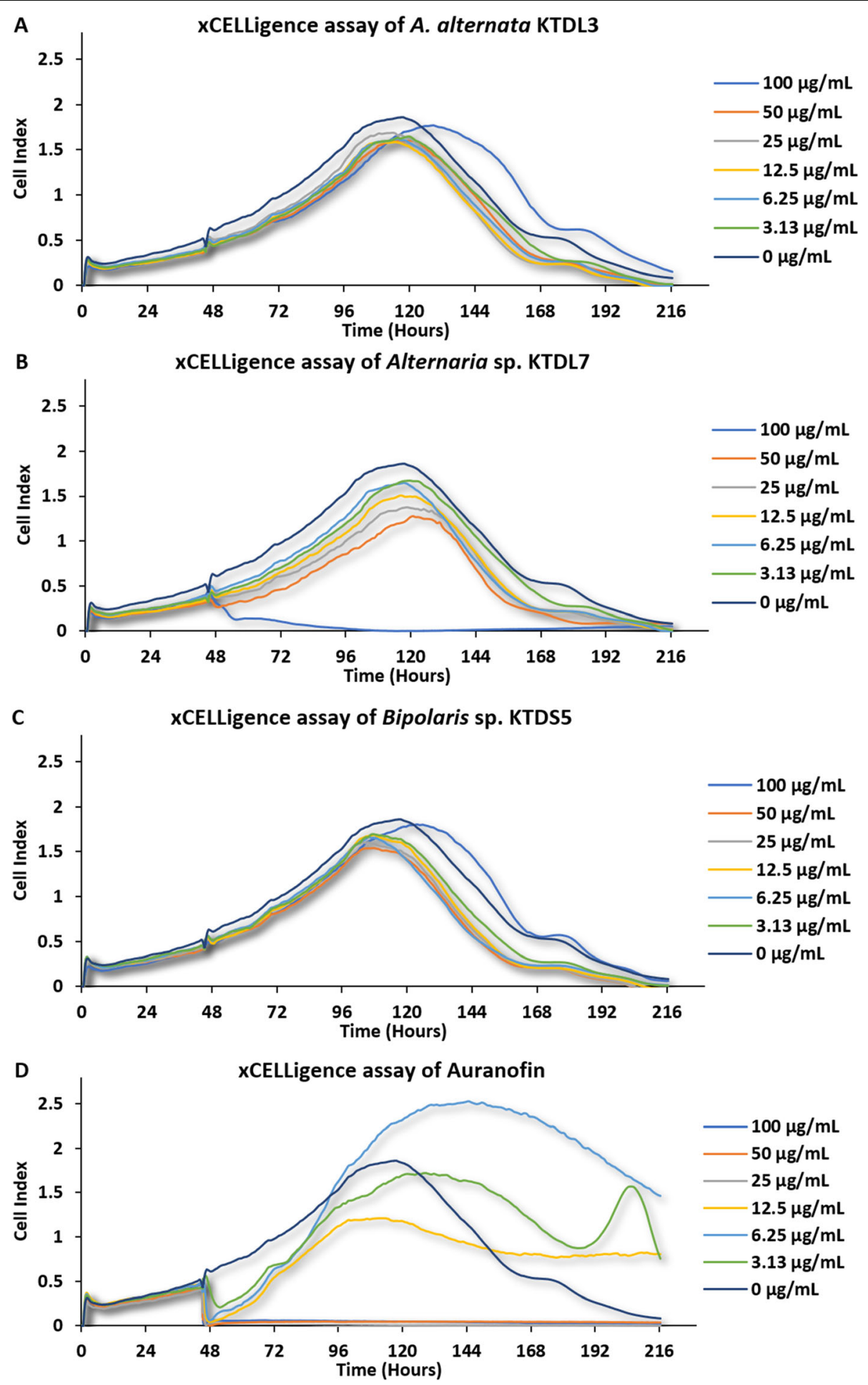

Fig. 3 Real-time analysis of the bioactivity of crude fungal extracts on UMG87 glioblastoma cells. Extracts from Alternaria alternata KTDL3 (a), Alternaria sp. KTDL7 (b), and Bipolaris sp. KTDS5 (c) were administered in six concentrations ranging from 0 to $100 \mu \mathrm{g} / \mathrm{mL}$ on the 45 th hour on the timeline and the response of the cells was monitored up until the 216th hour. Cell viability was recorded as cell index, which is a relative change in measured impedance. Auranofin (d) was used as a positive control 


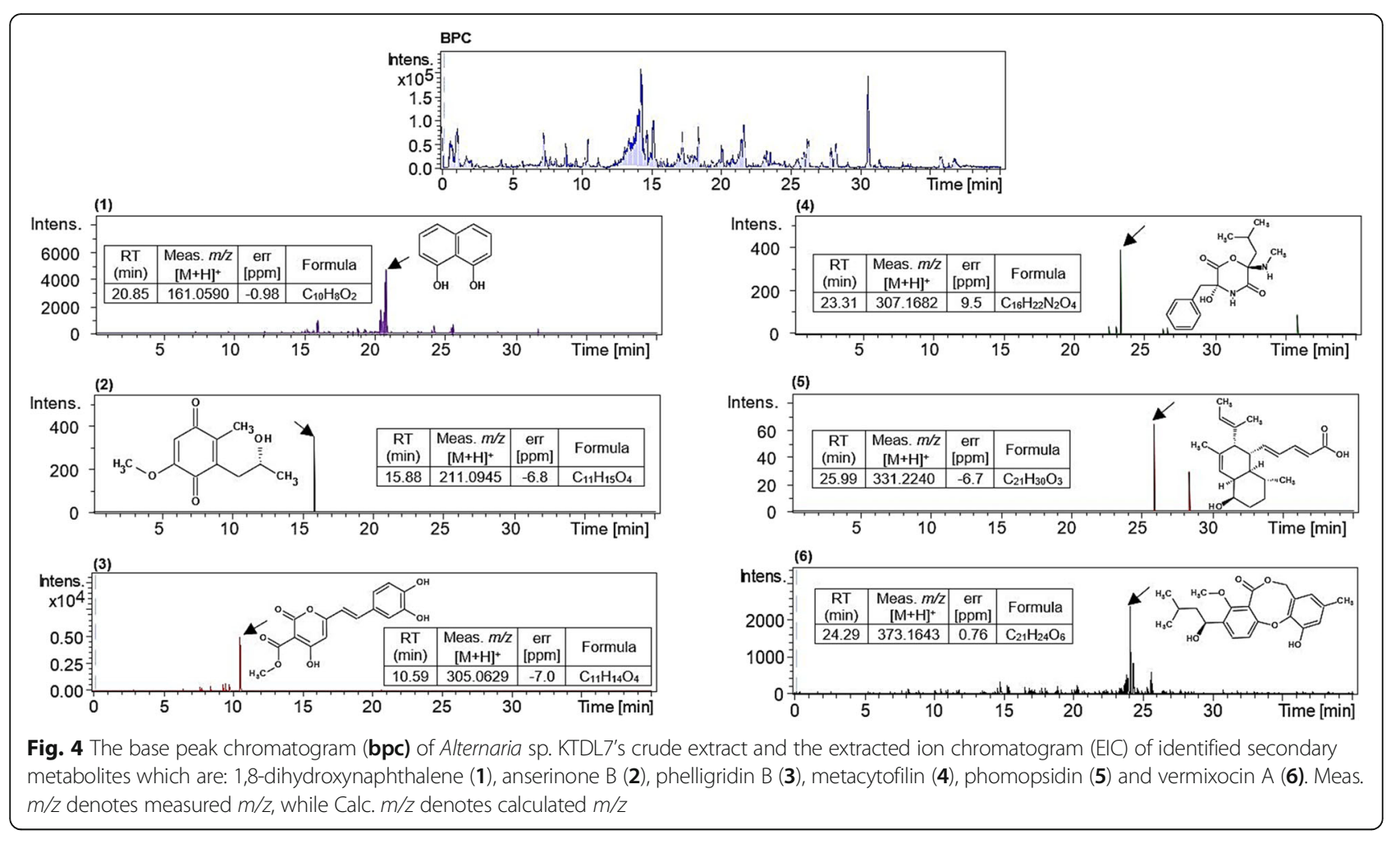

pigmented hyphae due to melanin production, a pigment known to improve stress tolerance of plant hosts by trapping and eliminating oxygen radicals generated during abiotic stress [44]. The endophyte Bipolaris sp. KTDS5 appeared to have a mixture of black pigmented and nonpigmented white colonies, where the black pigment was also evidence of fungal melanin production [45]. Endophytes that produce melanized septate hyphae and microsclerotia-like structures are commonly known as "Dark Septate Endophytes" (DSE), they are collectively thought to improve nutrient acquisition and stress tolerance in plants [46]. $R$. mucilaginosa KTDS2 had pink colonies and G. castaneus KTDL1, Colletotrichum sp. KTDL4, Talaromyces sp. KTDL6, S. schenckii KTDL8, Trichoderma sp. KTDL11 and P. crystallinus KTDS1 all had a cream-white appearance. Pigments in fungi are chiefly produced in the mevalonate pathway and include carotenoids such as lycopene, $\gamma$-carotene, $\beta$-carotene, cantaxanthin, astaxanthin, neurosporaxanthin and torulene [47]. Besides contributing to the metabolism of the host plant, natural pigments produced by (endophytic) fungi have great potential in the food and beverage industry where synthetic pigments are often toxic and carcinogenic [48]. The specific individual roles played by each fungal isolate in the plant-endophyte relationship with $D$. stramonium are still yet to be better understood.

Among the isolated fungal endophytes in this study, significant and selective cytotoxic activity was observed from the crude extract of Alternaria sp. KTDL7 on
UMG87 glioblastoma cells in the MTS assay. The highest cytotoxic activity of this crude extract was observed at 50 and $100 \mu \mathrm{g} / \mathrm{mL}$, indicating a dose-response dependent activity. Still on the same fungal extract and cell line, an interesting observation was noted whereby the actual cell viability of the $50 \mu \mathrm{g} / \mathrm{mL}$ treatment $(2.68 \%)$ was found to be $1.61 \%$ lower than that of double the concentration, the $100 \mu \mathrm{g} / \mathrm{mL}(4.29 \%)$ treatment (Fig. 1). Upon testing the two means with multivariate analysis of variance, no significant statistical difference in their activity was found as the $p$-value $P>0.05$. Mechanisms underlying the selective cytotoxicity observed from the crude extract of Alternaria sp. KTDL7 were not investigated as this was beyond the scope of this study.

In the xCELLigence assay, the cytotoxic activity of the crude extract of Alternaria sp. KTDL7 at $100 \mu \mathrm{g} / \mathrm{mL}$ on UMG87 glioblastoma cells was observed to be much higher and not comparable to that of the same extract at $50 \mu \mathrm{g} / \mathrm{mL}$ (Fig. 3). The resulting differences in the behavior of this extract when assayed in the xCELLigence and MTS assay can be explained by the fact that both assays target different markers. The xCELLigence assay determines cell viability indirectly by measuring impedance in 96 well plates, thus cells adhered to the bottom of the wells with micro-electrodes will increase electrical resistance which is recorded as a high cell index. Detachment of cells from the bottom of the plate will result lower electrical resistance, hence lower cell index values. The 
MTS assay targets the activity of mitochondrial activity of living cells.

Auranofin was used in this study as a positive control in both the MTS and xCELLigence assays. Originally, this drug was approved for the treatment of rheumatoid arthritis. Continued studies however have shown that auranofin (in its individual and combination treatments with other agents) exhibits anticancer activity by inhibiting thioredoxin reductase [49], and thus inducing apoptosis, among other anticancer mechanisms. A number of cancer cell lines that have shown susceptibility to auranofin include MCF-7 human breast cancer cells [50, 51], Hep3B human hepatocellular carcinoma cells [52], LNcap and 22RV1 human prostate cancer cells [53], SKOV3 ovarian cancer cells [54], HCT116 and HT-29 colorectal cancer cells [55], human glioblastoma multiforme cells [56], and 10 non-small lung cancer cell lines [57]. The cytotoxic mechanism of action of auranofin on UMG87 glioblastoma cells is still yet to be fully explained, however its xCELLigence profile in this study lead to the assumption that it has an intracellular target, most likely a gene involved in metabolism since low doses of the drug induced resistance and hypermetabolism (Fig. 3).

Considering the gap in knowledge about bioactive extracts from endophytic fungi, it became necessary to perform secondary metabolite profiling of the cytotoxic Alternaria sp. KTDL7's crude extract. After analyzing LCQTOF-MS/MS spectrum data for Alternaria sp. KDTL7's crude extract for previously characterized compounds, seven secondary metabolites (Compounds $\mathbf{1}$ to 6) were identified from compound libraries.

Compound $\mathbf{1}$ (1,8-dihydroxynaphthalene) is a key intermediate in the synthesis of dihydroxynaphtalene (DHN)-melanin, commonly found in fungi and is synthesized via the polyketide pathway [58]. Fungi within the Alternaria genus studied up to date have been shown to be DHN-melanin producers, including $A$. alternata 15A [59], and A. infectoria CBS 137.90 [60]. DHN-melanin was tested for antifungal activity on clinical isolates and was found to have a half-minimum inhibitory concentration $\left(\mathrm{MIC}_{50}\right)$ of $128 \mu \mathrm{g} / \mathrm{mL}$ for Aspergillus flavus, $64 \mu \mathrm{g} / \mathrm{mL}$ for A. niger, $256 \mu \mathrm{g} / \mathrm{mL}$ for A. fumigatus and $512 \mu \mathrm{g} / \mathrm{mL}$ for A. tamarii [61].

Compound 2 (anserinone) is a polyketide that has been previously isolated from the cophrophilous Podospora anserine, where it was found to reduce radial growth of Sordaria fimicola and Ascobolus furfuraceus by 50 and $37 \%$ respectively $[62,63]$. In that same study, anserinone $\mathrm{B}$ was found to be moderately cytotoxic with an average $\mathrm{IC}_{50}$ of $4.4 \mu \mathrm{g} / \mathrm{mL}$ after being tested on the National Cancer Institute's 60 human tumor cell line panel [62, 64].
Compound 3 (phelligridin B) is a styrylpyrone derivative which is synthesized within the shikimate and acetate pathways [65]. This secondary metabolite has been found in ethanolic extracts of Phellinus linteus (Sang Huang) and has been shown to exhibit cytotoxic activity against Bel-7402 cells at an $\mathrm{IC}_{50}$ of $0.050 \mu \mathrm{M}$ [66].

Compound 4 (metacytofilin) has been previously identified from the culture filtrate of Metarhizium sp. TA2759 and possess immunosuppressive properties [67]. It is a two-residue depsipeptide synthesized by nonribosomal peptide synthases in combination with polyketide synthase [68].

Compound $\mathbf{5}$ (phomopsidin) is an interesting polyketide which has been previously isolated from a marine derived Phomopsis sp. TUF95F47 [69]. This secondary metabolite showed inhibition of microtubule assembly at an $\mathrm{IC}_{50}$ of $5.7 \mu \mathrm{M}$ in the in vitro assembly analysis of porcine brain tubulin assay [70, 71].

Compound 6 (vermixocin) is a diphenyl ether derivative, previously isolated from a marine fungus, Talaromyces sp. LF458 [71]. Vermixocins were previously found to inhibit RNA synthesis as they interfered with incorporation of labeled uridine in a murine P388 leukemia cell line [72].

Commonly known secondary metabolites which have been previously identified in extracts of fungi from the Alternaria genus include alternariol, alternariol monomethyl ether, tentoxin, altesertin, alteichin, stemphyltoxin, altersolanol, altenusin and tenuazenoic acid were not detected in this study [73]. A possible explanation for this occurrence is that different fungal strains in the same genus have the biosynthetic capability of producing a wide variety of chemically diverse secondary metabolites [74]. The type of method and solvent used in the extraction process may also significantly affect the nature and quantity of secondary metabolites recovered [75]. Some researchers have reported the use of acidified extracting organic solvents or acidified filtrate broth to increase the solubility of fungal secondary metabolites in organic solvents [76].

\section{Conclusions}

This study provides evidence that the ethyl acetate crude extract of Alternaria sp. KTDL7 exerts a notable dosedependent and selective cytotoxic activity on UMG87 glioblastoma cells. Metabolite profiling also showed that Alternaria sp. KTDL7 is capable of producing compounds similar to those from terrestrial plants and marine fungi belonging to different genera, as is the case with compounds $\mathbf{2}$ to $\mathbf{6}$. This further supports the notion that more complex chemical structural scaffolds with interesting bioactivities are likely to be harbored by fungal symbionts from diverse origins. Further studies will be aimed at isolating and characterizing the cytotoxic pure 
compounds from the crude extract of Alternaria sp. KTDL7 and determining their mechanism of action, which could result in the development of a fungal-based drug for glioblastoma multiforme treatment.

\section{Supplementary information}

Supplementary information accompanies this paper at https://doi.org/10. 1186/s12906-019-2752-9.

Additional file 1. Phylogenetic relationships of fungal endophytes from healthy leaves, stems and seeds of D. stramonium inferred based on ITS1 and ITS4 sequences. The numbers at branch nodes represent maximum likelihood bootstrap values from analyses with 1000 replicates. In boldface are fungal endophytes isolated from D. stramonium (GenBank accession number, name and isolate code). Fungal endophytes according to morphological characteristics on PDA plates, where group A are filamentous fungi, $B$ and $C$ being non-filamentous fungi. Evolutionary analyses were conducted in MEGA7 (Kumar et al., 2016).

Additional file 2. LC-QTOF-MS-MS_Analysis. Mass spectra for the crude extract of Alternaria sp. KTDL7 and the mass fragment patterns of the identified compounds: 1,8-dihydroxynaphthalene (1), anserinone B (2), phelligridin B (3), metacytofilin (4), phomopsidin (5) and vermixocin A (6).

\section{Abbreviations}

CID: Collision induced dissociation; DMSO: Dimethyl sulfoxide;

ESI(+): Electrospray ionization (positive mode); ITS: Internal transcribed spacer region; LC-QTOF-MS/MS: Liquid chromatography couple to quadrupole timeof-flight with tandem mass spectrometry; LSD: Least significant difference; MANOVA: Multivariate-analysis of variance; MTS: 3-(4,5-dimethylthiazol-2-yl)-5(3-carboxymethoxyphenyl)-2-(4-sulfophenyl)-2H-tetrazolium; NCBI: National Center for Biotechnology Information; PBS: Phosphate buffered saline; PDA: Potato dextrose agar; PDB: Potato dextrose broth; PVDF: Polyvinylidene fluoride; rDNA: Ribosomal deoxyribonucleic acid; RP-UHPLC: Reverse phase ultra-high-performance liquid chromatography; RTCA: Real time cell analyzer; SD: Standard deviation; UHPLC: Ultra-high-performance liquid chromatography.

\section{Acknowledgements}

The authors would like to greatly acknowledge Rashid Ahmed Mosam for depositing the voucher specimen at the herbarium and the also Eric Morifi, Thapelo Mbele and Refilwe Moepya for assisting with the mass spectrometry experiments.

\section{Author contributions}

VM conceptualized the study; VM, LM and MM designed the methods; KT, $\mathrm{NU}$ and TS prepared samples, performed analytical experiments and drafted the manuscript; RH analyzed data and assisted in drafting the manuscript; VM, MM, LM and EG supervised, validated experiments and assisted in data analysis. All authors read and approved the manuscript.

\section{Funding}

Funding for experimental consumables came from South African National Research Foundation, grant number (Thuthuka NRF Rating Track): TTK150713125714; TTK150612119319 and the Department of Science and Technology through the Artificial Wetland Research (AWARE) project. The funding bodies had no role in study design, collection, analysis, data interpretation and in writing the manuscript.

\section{Availability of data and materials}

The datasets supporting the conclusions of this article are available in the Mendeley Data repository, https://data.mendeley.com/datasets/xt4br8zmtz/1

Ethics approval and consent to participate

No permissions were required to collect the plant obtained for this study.

\section{Consent for publication}

Not applicable.

\section{Competing interests}

The authors declare that they have no competing interests.

\section{Author details}

${ }^{1}$ Department of Biotechnology and Food Technology, Faculty of Science, University of Johannesburg, Box 17011, Doornfontein, Johannesburg, PO 2028, South Africa. ${ }^{2}$ South African Medical Research Council Centre for Tuberculosis Research, Division of Molecular Biology and Human Genetics, Department of Biomedical Sciences, Stellenbosch University, Tygerberg 7505, South Africa. ${ }^{3}$ Department of Chemical Engineering, Faculty of Engineering and the Built Environment, University of Johannesburg, Box 17011 Doornfontein, Johannesburg, PO 2028, South Africa. ${ }^{4}$ Molecular Sciences Institute, School of Chemistry, University of the Witwatersrand, P.O Box Wits, Johannesburg 2050, South Africa.

Received: 28 February 2019 Accepted: 11 November 2019

Published online: 21 November 2019

\section{References}

1. Kumara PM, Shweta S, Vasanthakumari MM, Sachin N, Manjunatha BL, Jadhav SS, Ravikanth G, Ganeshaiah KN, Shaanker RU. Endophytes and plant secondary metabolite synthesis: molecular and evolutionary perspective. In: Verma VC, Gange AC, editors. Advances in endophytic research. Delhi: Springer India; 2014. p. 177-190.

2. Shehata HR, Lyons EM, Jordan KS, Raizada MN. Relevance of in vitro agar based screens to characterize the anti-fungal activities of bacterial endophyte communities. BMC Microbiol. 2016;16:1-7.

3. Kandel S, Joubert P, Doty S. Bacterial endophyte colonization and distribution within plants. Microorganisms. 2017;5:77.

4. Alvin A, Miller KI, Neilan BA. Exploring the potential of endophytes from medicinal plants as sources of antimycobacterial compounds. Microbiol Res. 2014;169:483-95.

5. Pansanit A, Pripdeevech P. Antibacterial secondary metabolites from an endophytic fungus, Arthrinium sp. MFLUCC16-1053 isolated from Zingiber cassumunar. Mycology. 2018;9:264-72.

6. Chen L, Zhang Q, Jia M, Ming Q, Yue W, Rahman K, Qin L. Endophytic fungi with antitumor activities: their occurrence and anticancer compounds. Crit Rev Microbiol. 2014;42:454-73.

7. Iranbakhsh A, Oshagi MA, Majd A. Distribution of atropine and scopolamine in different organs and stages of development in Datura stramonium L. (Solanaceae). Structure and ultrastructure of biosynthesizing cells. Acta Biol Cracov Ser Bot. 2006:48:13-8.

8. Soni P, Siddiqui AA, Dwivedi J, Soni V. Pharmacological properties of Datura stramonium L. as a potential medicinal tree: an overview. J Pharmacogn Phytochem. 2012;2:1002-8

9. Chávez D, Cui B, Hee-Byung CHB, García R, Mejía M, Farnsworth NR, Cordell GA, Pezzuto JM, Kinghorn AD. Reversal of multidrug resistance by tropane alkaloids from the stems of Erythroxylum rotundifolium. J Nat Prod. 2002;65: 606-10.

10. Mahdi T, Mohamed I, Yagi S. Endophytic fungal communities associated with ethno-medicinal plants from Sudan and their antimicrobial and antioxidant prospective. J For Pro Ind. 2014:3:248-56.

11. Aydi R, Abdallah B, Jabnoun-khiareddine H, Nefzi A, Mokni-tlili S, Daamiremadi $M$. Endophytic bacteria from Datura stramonium for Fusarium wilt suppression and tomato growth promotion. J Microb Biochem Technol. 2006;8:30-41.

12. Lou J, Yu R, Wang X, Mao Z, Fu L, Liu Y, Zhou L. Alternariol 9-methyl ether from the endophytic fungus Alternaria sp. Samif01 and its bioactivities. Brazi J Microbiol. 2016:47:96-101.

13. Christhudas IVSN, Kumar PP, Agastian P. Antimicrobial activity and HPLC analysis of tropane alkaloids in Streptomyces spp. isolated from Datura stramonium L. Asian J Pharm Clin Res. 2012;5:1-5.

14. Christhudas IVSN, Kumar PP, Agastian P. In vitro a-glucosidase inhibition and antioxidative potential of an endophyte species (Streptomyces sp. Loyola UGC) isolated from Datura stramonium L. Curr Microbiol. 2013; 67:69-76.

15. Uche-okereafor N, Sebola T, Tapfuma K, Mekuto K, Green E, Mavumengwana V. Antibacterial activities of crude secondary metabolite extracts from Pantoea species obtained from the stem of Solanum mauritianum and their effects on two cancer cell lines. Int J Env Res Public Heal. 2019;16:1-12. 
16. Alsohaili SA, Bani-hasan BM. Morphological and molecular identification of fungi isolated from different environmental sources in the northern eastern desert of Jordan. Jordan J Biol Sci. 2018;11:329-37.

17. Treves DS. Review of three DNA analysis applications for use in the microbiology or genetics classroom. J Microbiol Biol Educ. 2010;11:186-7.

18. Mcginnis S, Madden TL. BLAST: at the core of a powerful and diverse set of sequence analysis tools. Nucleic Acids Res. 2004;32:20-5.

19. Jeewon R, Ittoo J, Mahadeb D, Jaufeerally-Fakim Y, Wang H-K, Liu A-R. DNA based identification and phylogenetic characterisation of endophytic and saprobic fungi from Antidesma madagascariense, a medicinal plant in Mauritius. J Mycol. 2013;2013:1-10.

20. Kumar S, Stecher G, Tamura K. MEGA7: molecular evolutionary genetics analysis version 7.0 for bigger datasets. Mol Biol Evol. 2016;33:1870-4.

21. Tan X, Zhou Y, Zhou X, Xia X, Wei Y, He L, Tang H, Yu L. Diversity and bioactive potential of culturable fungal endophytes of Dysosma versipellis; a rare medicinal plant endemic to China. Sci Rep. 2018;8:1-9.

22. Ikechi-Nwogu CG, Elenwo EN. Comparative evaluation of growth media for the cultivation of fungal cultures. J Plant Pathol Microbiol. 2012;3:3-6.

23. Frisvad JC, Larsen TO, Vries RD, Meijer M, Houbraken J, Cabañes FJ, Ehrlich K, Samson RA. Secondary metabolite profiling, growth profiles and other tools for species recognition and important Aspergillus mycotoxins. Stud Mycol. 2007:9:31-7

24. Song J, Ma Q, Hu M, Qian D, Wang B, He N. The inhibition of miR-144-3p on cell proliferation and metastasis by targeting TOP2A in HCMV-positive glioblastoma cells. Molecules. 2018;23:1-13.

25. Handayani D, Rivai H, Mulyana R, Suharti N, Rasyid R, Hertiani T. Antimicrobial and cytotoxic activities of endophytic fungi isolated from mangrove plant Sonneratia alba Sm. J Appl Pharm Sci. 2018;8:49-53.

26. Tapfuma KI, Mekuto L, Makatini MM, Mavumengwana V. The LC-QTOF-MS/ MS analysis data of detected metabolites from the crude extract of Datura stramonium leaves. Data Br. 2019;25:1-4.

27. Changwa R, Abia W, Msagati T, Nyoni H, Ndleve K, Njobeh P. Multimycotoxin occurrence in dairy cattle feeds from the gauteng province of South Africa: A pilot study using UHPLC-QTOF-MS/MS. Toxins (Basel). 2018;10:1-21.

28. Hoffmann T, Krug D, Hüttel S, Müller R. Improving natural products identification through targeted LC-MS/MS in an untargeted secondary metabolomics workflow. Anal Chem. 2014:86:10780-8.

29. Ruttkies C, Schymanski EL, Wolf S, Hollender J, Neumann S. MetFrag relaunched: incorporating strategies beyond in silico fragmentation. J Cheminform. 2016:8:1-16.

30. Li P, Wu Z, Wang Y. Biodiversity, phylogeny, and antifungal functions of endophytic fungi associated with Zanthoxylum bungeanum. Int J Mol Sci. 2016;17:1-24.

31. Gordon JL, Brown MA, Reynolds MM. Cell-based methods for determination of efficacy for candidate therapeutics in the clinical Management of Cancer. Diseases. 2018;6:1-13.

32. Wang P, Henning SM, Heber D. Limitations of MTT and MTS-based assays for measurement of antiproliferative activity of green tea polyphenols. PLoS One. 2010;5:1-10.

33. Steenkamp V, Gouws MC. Cytotoxicity of six south African medicinal plant extracts used in the treatment of cancer. SA J Bot. 2006;72:630-3.

34. Suffness M, Pezzuto JM. Assays related to cancer drug discovery. In: Hostettmann K, editor. Methods in plant biochemistry: assays for bioactivity, vol. 6. London: Academic Press; 1990. p. 71-133.

35. Haar CP, Hebbar P, Wallace GC IV, Das A, Vandergrift WA III, Smith JA, Giglio P, Patel SJ, Ray SK, Banik NL. Drug resistance in glioblastoma: A mini review. Neurochem Res. 2012;37:1192-200

36. Wolf S, Schmidt S, Müller-hannemann M, Neumann S. In silico fragmentation for computer assisted identification of metabolite mass spectra. BMC Bioinformatics. 2010;11:1-12.

37. Stierle A, Strobel G, Stierle S, Grothaus P, Bignami G. The search for a taxolproducing microorganism among the endophytic fungi of the Pacific yew. Taxus brevifolia J Nat Prod. 1995;58:1315-24

38. Ramalashmi K, Prasanna VK, Magesh K, Sanjana R, Siril JS. A potential surface sterilization technique and culture media for the isolation of endophytic bacteria from Acalypha indica and its antibacterial activity. J Med Plant Stud. 2018;6:181-4.

39. Sun J, Awakawa T, Noguchi H, Abe I. Induced production of mycotoxins in an endophytic fungus from the medicinal plant Datura stramonium $\mathrm{L}$. Bioorg Med Chem Lett. 2012;22:6397-400.
40. Puntscher H, Hankele S, Tillmann K, Attakpah E, Braun D, Kütt M, Del G, Aichinger G, Pahlke G, Höger H, Marko D, Warth B. First insights into Alternaria multi-toxin in vivo metabolism. Toxicol Lett. 2019;301:168-78.

41. Akimitsu K, Tsuge T, Kodama M, Yamamoto M, Otani H. Alternaria hostselective toxins: determinant factors of plant disease. J Gen Plant Pathol. 2014:80:109-22.

42. Thomma BPHJ. Alternaria spp.: from general saprophyte to specific parasite. Mol Plant Pathol. 2003;4:225-36.

43. Elgorban AM, Bahkali AH, Abdel-Wahab MA. Natural products of Alternaria sp., an endophytic fungus isolated from Salvadora persica from Saudi Arabia. Saudi J Biol Sci. 2018;xx:1-10.

44. Yuan ZL, Zhang CL, LiN FC, Kubicek CP. Identity, diversity, and molecular phylogeny of the endophytic mycobiota in the roots of rare wild rice (Oryzo granulate) from a nature reserve in Yunnan. China Appl Env Microbiol. 2010; 76:1642-52

45. Chand R, Kumar M, Kushwaha C, Shah K, Joshi AK. Role of melanin in release of extracellular enzymes and selection of aggressive isolates of Bipolaris sorokiniana in barley. Curr Microbiol. 2014;69:202-11.

46. Li X, He X, Hou L, Ren Y, Wang S, Su F. Dark septate endophytes isolated from a xerophyte plant promote the growth of Ammopiptanthus mongolicus under drought condition. Sci Rep. 2018:8:1-11.

47. Dufossé L. Microbial production of food grade pigments. Food Technol Biotech. 2006:44:313-21.

48. Venkatachalam M, Zelena M, Cacciola F, Ceslova L, Girard-valenciennes E, Clerc P, Dugo P, Mondello L, Fouillaud M, Rotondo A, Giu D, Dufossé L. Partial characterization of the pigments produced by the marine-derived fungus Talaromyces albobiverticillius 30548. Towards a new fungal red colorant for the food industry. J Food Compost Anal. 2018;67:8-47.

49. Zhang X, Selvaraju K, Saei AA, D'Arcy P, Zubarev RA, Arnér ES, Linder S. Repurposing of auranofin: thioredoxin reductase remains a primary target of the drug. Biochimie. 2019;162:46-54.

50. Lee JE, Kwon YJ, Baek HS, Ye DJ, Cho E, Choi HK, Oh KS, Chun YJ. Synergistic induction of apoptosis by combination treatment with mesupron and auranofin in human breast cancer cells. Arch Pharm Res. 2017:40:746-59.

51. Ye DJ, Kwon YJ, Baek HS, Cho E, Kwon TU, Chun YJ. Combination treatment with auranofin and nutlin-3a induces synergistic cytotoxicity in breast cancer cells. J Toxicol Environ Heal A. 2019;82:626-37.

52. Hwang-Bo H, Lee WS, Nagappan A, Kim HJ, Panchanathan R, Park C, Chang SH, Kim ND, Leem SH, Chang YC, Kwon TK, Cheong JH, Kim GS, Jung JM, Shin SC, Hong SC, Choi YH. Morin enhances auranofin anticancer activity by up-regulation of DR4 and DR5 and modulation of $\mathrm{BCl}-2$ through reactive oxygen species generation in Hep3B human hepatocellular carcinoma cells. Phytother Res. 2019;33:1384-93.

53. Liu N, Guo Z, Xia X, Liao Y, Zhang F, Huang C, Liu Y, Deng X, Jiang L, Wang $X$, Liu J, Huang $H$. Auranofin lethality to prostate cancer includes inhibition of proteasomal deubiquitinases and disrupted androgen receptor signaling. Eur J Pharmacol. 2019;846:1-11

54. Park SH, Lee JH, Berek JS, Hu MC. Auranofin displays anticancer activity against ovarian cancer cells through $\mathrm{FOXO} 3$ activation independent of p53. Int J Oncol. 2014:45:1691-8.

55. Han Y, Chen P, Zhang Y, Lu W, Ding W, Luo Y, Wen S, Xu R, Liu P, Huang P. Synergy between auranofin and celecoxib against colon cancer in vitro and in vivo through a novel redox-mediated mechanism. Cancers. 2019;11:1-18.

56. Skaga E, Skaga $\mid \varnothing$, Grieg Z, Sandberg CJ, Langmoen IA, Mo EOV. The efficacy of a coordinated pharmacological blockade in glioblastoma stem cells with nine repurposed drugs using the CUSP9 strategy. J Cancer Res Clin Oncol. 2019;145:1495-507.

57. Li H, Hu J, Wu S, Wang L, Cao X, Zhang X, Dai B, Cao M, Shao R, Zhang R, Majidi M, Ji L, Heymach JV, Wang M, Pan S, Minna J, Mehran RJ, Swisher SG, Roth JA, Fang B. Auranofin-mediated inhibition of PI3K/AKT/mTOR axis and anticancer activity in non-small cell lung cancer cells. Oncotarget. 2016;7: 3548-58.

58. Sone Y, Nakamura S, Sasaki M, Hasebe F, Kim S-Y, Funa N. Bacterial enzymes catalyzing the synthesis of 1,8-dihydroxynaphthalene, a key precursor of dihydroxynaphthalene melanin, from Sorangium cellulosum. Appl Env Microbiol. 2018:84:1-13.

59. Kimura N, Tsuge T. Gene cluster involved in melanin biosynthesis of the filamentous fungus Alternaria alternata. J Bacteriol. 1993;175:4427-35.

60. Fernandes C, Prados-rosales R, Silva BMA, Nakouzi-naranjo A, Zuzarte M, Chatterjee S, Stark RE, Casadevall A, Gonçalves T. Activation of melanin 
synthesis in Alternaria infectoria by antifungal drugs. Antimicrob Agents Chemother. 2016;60:1646-55.

61. Raman NM, Ramasamy S. Genetic validation and spectroscopic detailing of DHN-melanin extracted from an environmental fungus. Biochem Biophys Rep. 2017;12:98-107.

62. Wang HJ, Gloer KB, Gloer JB, Scott JA, Malloch D. Anserinones a and B: new antifungal and antibacterial benzoquinones from the coprophilous fungus Podospora anserina. J Nat Prod. 1997;60:629-31.

63. Sarrocco S. Dung-inhabiting fungi: a potential reservoir of novel secondary metabolites for the control of plant pathogens. Pest Manag Sci. 2016;72: 643-52.

64. Shoemaker RH. Major events in the development, implementation and use of the NCl60 cell lines. Nat Rev Cancer. 2006;6:813-24.

65. Dewick PM. Medicinal natural products: a biosynthetic approach. 2nd ed. West Sussex: John Wiley \& Sons Ltd; 2002

66. Silva DDD, Rapior S, Sudarman E, Hyde KD. Bioactive metabolites from macrofungi: ethnopharmacology, biological activities and chemistry. Fungal Divers. 2013;62:1-40.

67. lijima M, Masuda T, Nakamura H, Naganawa H, Okami Y, Ishizuka M, Takeuchi T. Metacytofilin, a novel immunomodulator produced by Metarhizium sp. TA2759. J Antibiot. 1992;45:1553-6.

68. Wang X, Gong X, Li P, Lai D. Structural diversity and biological activities of cyclic depsipeptides from fungi. Molecules. 2018;23:1-49.

69. Namikoshi M, Kobayashi H, Yoshimoto T, Hosoya T. Phomopsidin, a new inhibitor of microtubule assembly produced by Phomopsis sp. isolated from coral reef in Pohnpei. J Antibiot. 1997:50:890-2.

70. Liang ZQ, Cao N, Song ZK, Wang X. In vitro porcine brain tubulin assembly inhibition by water extract from a Chinese medicinal herb, Tripterygium hypoglaucum hutch. World J Gastroenterol. 2006;12:1133-5.

71. Wu B, Ohlendorf B, Oesker V, Wiese J, Malien S, Schmaljohann R, Imhoff JF. Acetylcholinesterase inhibitors from a marine fungus Talaromyces sp. strain LF458. Mar Biotechnol. 2014;17:110-9.

72. Nicoletti R, Ciavatta LM, Buommino E, Tufano MA. Antitumor extrolites produced by Penicillium species. Int J Biomed Pharm Sci. 2008;2:1-23.

73. Escrivá $L$, Oueslati $S$, Font $G$, Manyes L. Alternaria mycotoxins in food and feed: an overview. J Food Qual. 2017;2017:1-20.

74. Vadlapudi V, Borah N, Yellusani KR, Gade S, Reddy P, Rajamanikyam M, Vempati LNS, Gubbala SP, Chopra P, Upadhyayula SM, Amanchy R. Aspergillus secondary metabolite database, a resource to understand the secondary metabolome of Aspergillus genus. Sci Rep. 2017;7:1-10.

75. Van Ngo T, Scarlett CJ, Bowyer MC, Ngo PD, Van Vuong Q. Impact of different extraction solvents on bioactive compounds and antioxidant capacity from the root of Salacia chinensis L. J Food Qual. 2017;2017:1-8.

76. Samiee SM, Moazami N, Haghighi S, Mohseni FA, Bakhtiari MR. Screening of lovastatin production by filamentous fungi. Iran Biomed J. 2003;7:29-33.

\section{Publisher's Note}

Springer Nature remains neutral with regard to jurisdictional claims in published maps and institutional affiliations.

Ready to submit your research? Choose BMC and benefit from:

- fast, convenient online submission

- thorough peer review by experienced researchers in your field

- rapid publication on acceptance

- support for research data, including large and complex data types

- gold Open Access which fosters wider collaboration and increased citations

- maximum visibility for your research: over $100 \mathrm{M}$ website views per year

At BMC, research is always in progress.

Learn more biomedcentral.com/submissions 